
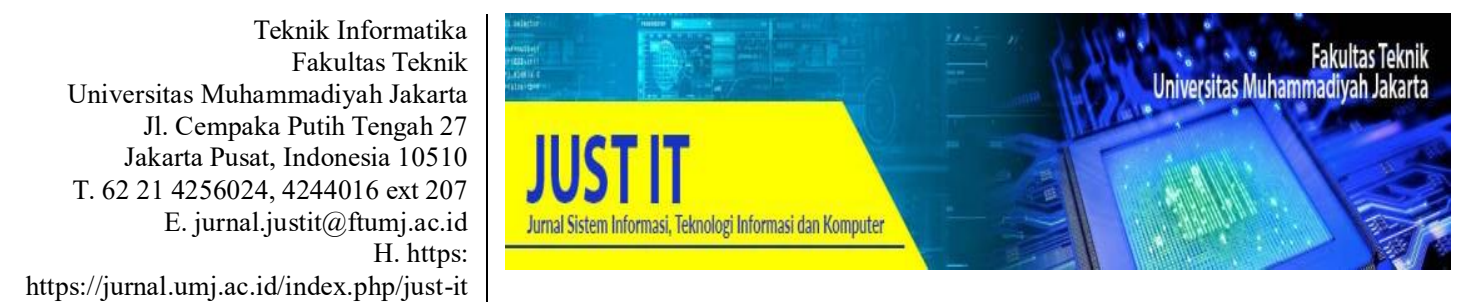

\title{
SISTEM MONITORING SUHU DAN KELEMBABAN RUANG PRODUKSI BERBASIS WIRELESS SENSOR NETWORK PADA PT. XXX MANUFACTURING SERVICES INDONESIA
}

\author{
Susilawati $^{1}$, Suseno ${ }^{2}$, dan Chaerur Rozikin ${ }^{3}$ \\ 1,2,3 Teknik Informatika Fakultas Ilmu Komputer Universitas Singaperbangsa Karawang \\ susilawati.sobur@staff.unsika.ac.id ${ }^{1}, 11441177004302 @$ student.unsika.ac.id² , \\ chaerur.rozikin@staff.unsika.ac.id ${ }^{3}$
}

\begin{abstract}
Abstrak
Sistem monitoring suhu dan kelembaban udara berbasis internet of things merupakan salah satu langkah antisipasi terhadap kerusakan bahan material pada proses produksi komponen semikonduktor, karena suhu dan kelembaban udara merupakan salah satu faktor penyebab rusaknya material dan berkurangnya kualitas komponen semickonduktor baik secara fisik maupun secara fungsional. Penelitian ini bertujuan membuat sebuah sistem monitoring suhu dan kelembaban ruang produksi komponen semikonduktor. Penelitian ini memiliki beberapa tahapan yaitu pengumpulan data, identifikasi kebutuhan, perancangan sistem, instalasi software dan hardware, dan pengujian sistem. Sistem yang dibuat dalam penelitian ini mengimplementasikan teknologi IoT (internet of things) sebagai penghubung antara node sensor dan node monitor dengan menggunakan protokol HTTP. Sistem ini menggunakan sensor DHT22 dan microcontroller Nodemcu v.3 yang tertanam modul wifi esp8266 sebagai pengirim data melalui jaringan internet ke sebuah server. Berdasarkan hasil pengujian, node sensor berhasil mengirimkan data ke node monitor(server) secara kontinus dengan interval 1 menit dengan akurasi suhu 96,2\% ,akurasi kelembaban 90,0\% dan berhasil mengirimkan notifikasi peringatan ketika terjadi kondisi abnormal.
\end{abstract}

Kata Kunci: Nodemcu,esp 8266, WSN, Sensor dht22, Sistem monitoring.

\begin{abstract}
The monitoring system of temperature and humidity based on internet of things is one of the anticipatory steps to damage material in the process of producing semiconductor components, because temperature and humidity are one of the factors causing material damage and reduced quality of semickonductor components both physically and functionally. This study aims to create a system for monitoring temperature and humidity of semiconductor component production rooms. This study has several stages, namely data collection, identification of needs, system design, software and hardware installation, and system testing. The system created in this study implements the IoT (internet of things) technology as a link between sensor nodes and monitor nodes using the HTTP protocol. This system uses a DHT22 sensor and a Nodemcu v.3 microcontroller which is embedded with the esp8266 wifi module as the sender of data over the internet to a server. Based on the test results, the sensor node successfully sends data to the monitor node (server) continuously at 1 minute intervals with $96.2 \%$ temperature accuracy, $90.0 \%$ humidity accuracy and successfully sends a warning notification when abnormal conditions occur.
\end{abstract}

Keywords: Nodemcu,esp 8266, WSN, Sensor dht22, Monitoring System. 


\section{Pendahuluan}

Dalam dunia industri elektronika di dunia Salah satunya perkembangan produk semiconduktor dan industri device elektronika yang dari tahun ke tahun digunakan diberbagai produk elektronika dan diterapkan sebagai alat bantu mempermudah kegiatan manusia untuk memenuhi berbagai kebutuhan manusia di dunia. PT. XXX yang berdiri pada tahun 1996 merupakan perusahaan yang bergerak dibidang elektronik yang berada di Kawasan Karawang International Industrial City (KIIC). Perusahaan ini memproduksi komponen semiconduktor, Salah satu produk yang diproduksi adalah kartu pintar (smart card) Pembuatan kartu elektronik tersebut dalam proses produksinya membutuhkan ruang yang sangat bersih, suhu yang stabil dan kelembaban udara yang cukup. Apabila kondisi ruang produksi tidak sesuai dengan kriteria yang ditentukan oleh perusahaan maka akan menghasilkan produk yang berkualitas kurang baik bahkan tidak bisa berfungsi sama sekali. Produk cacat bisa terjadi karena beberapa penyebab, salah satu penyebabnya suhu dan kelembaban ruang produksi yang tidak sesuai dengan kriteria yang ditentukan. Dari hasil pengumpulan data,berikut ini gambar nilai suhu dan kelembaban udara diruang produksi dalam kurun waktu 4 bulan terakhir.

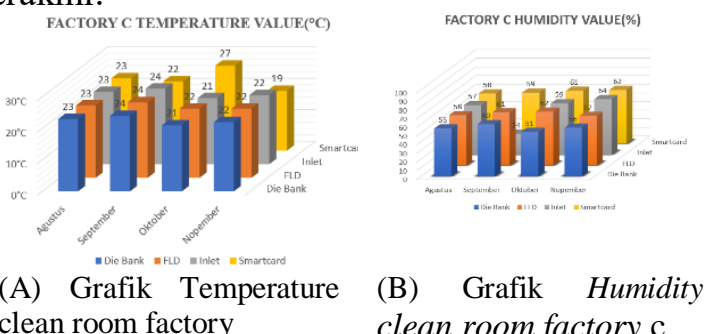

clean room factory clean room factory $\mathrm{c}$

Gambar 1. Grafik Temperature (A) dan Humidity (B) Clean Room Factory

(Sumber :Dokumen Departemen Quality Control PT. XXX 2017)

Data-data pada Gambar 1 (A) dan (B) diperoleh dari hasil alat ukur hygrothemograph yang disalin ulang oleh pihak Facility Engineering dan pihak Procces Control dengan membaca kertas pada alat ukur ini, pembacaan dilakukan tiga kali dalam sehari pada shift pagi, shift sore, dan shift malam. Hygrothemograph adalah alat ukur konvensional yang sangat rentan terhadap getaran dan goncangan yang membuat hasil ukur menjadi tidak akurat. Selain itu sering kali karena pengecekan suhu dan kelembaban ruang produksi dilakukan manusia yang sangat rentan sekali terhadap kesalahan pembacaan dan penulisan dan kegiatan pengecekan ruang produksi hanya dilakukan tiga kali sehari sementara rung produksi PT. XXX dari factory A,B,C dan D mempunyai posisi yang berjauhan, apabila kondisi beberapa ruang produksi keluar dari spesifikasi yang ditentukan akan sulit terkontrol sementara material yang ada dalam ruang produksi akan mengalami korosi apabila dalam dua jam kondisi ruangan tidak diperbaiki dan menyebabkan kualitas mattrial berkurang bahkan matrial menjadi rusak. Pelangganpun tidak akan besedia menerima produk berkualitas buruk. Faktor keterlambatan penanganan suhu dan kelembaban ruangan yang jauh dari spesiikasi karena tidak adanya peringatan dini didalam ruang produksi dan terlambatnya informasi menyebabkan produktifitas menurun, sehingga membuat keterlambatan pengiriman kepada pelanggan. Penelitian terkait yang dilakukan oleh Muladi dengan tujuan penelitian ini adalah memonitoring ruang kelas menggunakan Wireless Sensor Network untuk memantau keadaan suhu, kelembaban dan kadar $\mathrm{CO} 2$ pada udara di ruang belajar yang sesuai dengan kebutuhan fisik manusia (Muladi et. al. 2016). Penelitian berikutnya tentang Pengiriman data suhu berbasis internet of things menggunakan protokol MQTT menggunankan arduino uno dan esp8266 (budioko, 2016). Penelitian tentang wireless sensor network untuk akuisis data kelembaban dan suhu tanah bertujuan untuk mengakuisisi data suhu dan kelembaban dari berbagai node yang disebarkan di lahan pertanian kemudian nilai sensor dari node dikirimkan melalui teknologi wsn dan nilai sensor yang dirima di server diolah dan dijadikan dasar untuk membukan dan menutup saluran irigasi secara otomatis (Rozikin, et. al. 2017) Berbeda dengan penelitian sebelumnya ,penelitian ini akan menggunakan microcontroller nodemcu yang sangat praktis karena didalamnya tertanam modul wifi esp8266 12-E dan menggunakan protokol HTTP. 


\section{Metodologi Penelitian}

Metodologi penelitian yang digunakan pada penelitian ini adalah dengan metode pengumpulan data dengan metode literatur dan observasi, dan metode pengembangan sistem hardware menggunakan metode yang dibuat sendiri dengan menyesuaikan kebutuhan dan fungsi sistem hardware itu sendiri dengan alur penelitian seperti pada gambar dibawah ini.

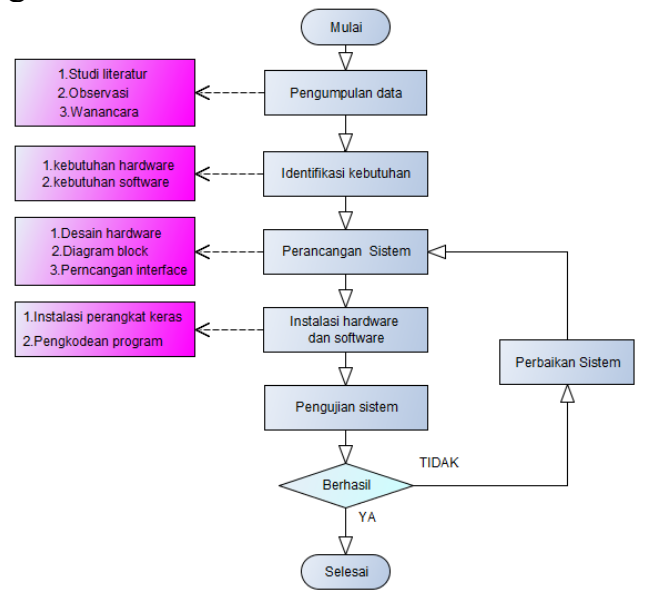

Gambar. 2. Alur tahapan penelitian

Metode Pengumpulan data dalam penelitian ini dilakukan guna memperoleh data-data untuk dianalisa dan diolah, sehingga ditemukan permasalahan apa saja yang ada. Penelitian ini diharapkan dapat menghasilkan jalan keluar atau penyelesaian dari permasalahan tersebut. Adapun metode yang digunakan dalam pengumpulan data adalah studi literatur, observasi dan wawancara.

Alat yang digunakan pada penelitian ini berupa perangkat keras dan perangkat lunak yang akan digunakan sebagai pengembangan sistem monitoring suhu dan kelembaban udara dan dapat di akses melalui website. Kebutuhan perangkat keras dapat dilihat pada tabel 1 dan kebutuhan perangkat lunak dapat dilihat pada tabel 2.

TABEL 1.

KEBUTUHAN PERANGKAT KERAS

\begin{tabular}{|r|l|}
\hline No & Perangkat keras \\
\hline $\mathbf{1}$ & Personal Computer \\
\hline $\mathbf{2}$ & Wireless router \\
\hline $\mathbf{4}$ & Led indikator \\
\hline $\mathbf{5}$ & Power supply micro usb dcv $2 \mathrm{~A}$ \\
\hline $\mathbf{6}$ & Alarm Buzzer \\
\hline $\mathbf{7}$ & Modul wifi nodemcu v.3 \\
\hline
\end{tabular}

TABEL 2.

KEBUTUHAN PERANGKAT LUNAK

\begin{tabular}{|c|l|}
\hline No & Perangkat Lunak \\
\hline $\mathbf{1}$ & Sistem operasi Windows 7 \\
\hline $\mathbf{2}$ & Software IDE Arduino \\
\hline $\mathbf{3}$ & Software YED graph editor \\
\hline $\mathbf{4}$ & Dokument editor Microsoft Office 2016. \\
\hline $\mathbf{5}$ & Software fritzing design \\
\hline $\mathbf{6}$ & Xampp \\
\hline
\end{tabular}

Perangkat keras merupakan unsur utama dalam penelitian ini, sehingga perlu dilakukan perancangan dan persiapan secara matang. Perancangan perangkat keras dilakukan dengan mendesain rankaian komponen. Ada beberapa komponen dalam perancangan sistem hardware seperti Nodemcu, sensor dht22, wifi router,buzzer komponen penunjang lainnya seperti adaptor, kabel penghubung dan lain-lain.

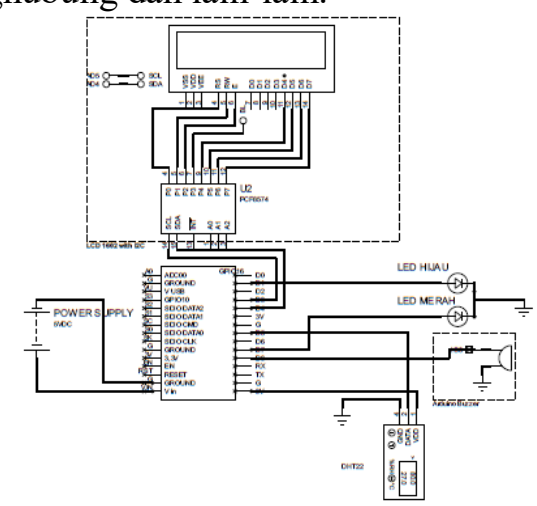

Gambar. 3. Diagram perancangan hardware

Prinsip kerja alat ini adalah Untuk Menyalakan Nodemcu V.3 dibutuhkan power supply dan ketika sensor dht22 mulai membaca kondisi suhu dan kelembaban udara di ruang produksi kemudian hasil pembacaan sensor akan dikirim oleh Nodemcu melalui wifi yang sudah tersambung jaringan internet Kemudian data dikirim ke server dan data dapat diakses menggunakan komputer melalui situs web.

Dalam tahap ini didalamnya ada proses pengkodean IDE Arduino untuk sistem yang dibuat,kemudian melakukan kompilasi dan upload program kedalam Nodemcu dan selain itu perakitan dilakukan dengan menggabungkan alat-alat yang sudah disiapkan dan dirancang sebelumnya. Tahapan ini membutuhkan ketelitian yang khusus 
karena perakitan dengan pengkodean harus sesuai dengan perancangan yang sudah dibuat sebelumnya.

Tahap pengujian dilakukan untuk menguji kinerja dari semua sistem yang telah dibangun. Tahapan ini melibatkan pengujian terhadap perangkat keras dan perangkat lunak. Sistem monitoring akan diuji guna memastikan apakah perangkat tersebut dapat digunakan dan berfungsi sebagaimana mestinya. Selanjutnya kinerja pada Nodemcu juga akan diuji, apakah Nodemcu berfungsi dengan baik dan terkoneksi dengan baik sehingga dapat mengirim data ke server IOT. Pada sensor suhu dan kelembaban juga diuji, yaitu apakah sensor bisa merespon dan mendeteksi suhu dan kelembaban di ruangan sekitarnya. Bahasa pemrograman yang diprogram ke dalam Nodemcu juga turut diuji, apakah sudah sesuai dengan algoritma yang telah dirancang dan tidak terdapat kesalahan penulisan program. Selain itu, pengujian dilakukan terhadap rangkaian elektronika untuk memeriksa apakah seluruh komponen sudah terhubung dengan baik. Pada tahap ini juga akan dilakukan pengujian kelebihan dan kekurangan pada alat ini, apakah alat yang dibuat sudah sesuai dengan perancangan awal yang diinginkan. Jika terdapat kesalahan maka akan dilakukan perbaikan dengan melakukan perancangan ulang sistem.

\section{Hasil dan Pembahasan}

Tahapan penelitian pertama adalah melakukan pengumpulan data dengan metodu studi literatur, wawancara, dan observasi. Hasil dari tahapan penelitian berupa data ini yaitu.

1. Penyempurnaan sistem monitoring suhu dan kelembaban udara pada ruang produksi komponen semiconduktor yang masih menggunakan alat ukur konvensional berupa higrotermograf.

2. Penyempurnaan kerja sistem yang sebelumnya harus dicek secara berkala dan dilakukan pencatatan ulang kemudian di kembangkan dengan membuat sistem pengiriman data secara otomatis.

3. Penambahan fitur berupa alarm sebagai peringatan dini ketika suhu terdeteksi tidak sesuai spesifikasi yang ditentukan.

Pada tahapan ini mengidentifikasi kebutuhan hardware dalam membuat sistem. Hasil dari identifikasi hardware seperti terlihat pada tabel 3 .

TABEL 3.

KEBUTUHAN HARDWARE

\begin{tabular}{|c|l|l|}
\hline No & \multicolumn{1}{|c|}{ Komponen } & \multicolumn{1}{|c|}{ Fungsi } \\
\hline 1 & $\begin{array}{l}\text { Modul wifi } \\
\text { Nodemcu }\end{array}$ & $\begin{array}{l}\text { Pengendali komponen } \\
\text { elektonika }\end{array}$ \\
\hline 2 & Sensor DHT 22 & $\begin{array}{l}\text { Pemdeteksi suhu dan } \\
\text { kelembaban udara }\end{array}$ \\
\hline 3 & $\begin{array}{l}\text { Piezo Electric } \\
\text { Buzzer 3-12VDC }\end{array}$ & alarm \\
\hline 4 & $\begin{array}{l}\text { LED indikator } \\
\text { 10mm hijau }\end{array}$ & Lampu indikator \\
\hline 5 & $\begin{array}{l}\text { LED indikator } \\
\text { 10mm merah }\end{array}$ & Lampu indikator \\
\hline 6 & LCD Display 1602 & Monitor display \\
\hline 7 & $\begin{array}{l}\text { 2C Serial } \\
\text { interface }\end{array}$ & $\begin{array}{l}\text { Transfer data ke dalam } \\
\text { komunikasi serial }\end{array}$ \\
\hline 8 & $\begin{array}{l}\text { Kabel jumper } \\
\text { Menghubungkan pin } \\
\text { antar komponen }\end{array}$ \\
\hline 9 & $\begin{array}{l}\text { Power supply } \\
\text { micro usb 5VDC }\end{array}$ & $\begin{array}{l}\text { Catu daya sistem } \\
\text { hardware }\end{array}$ \\
\hline 10 & Wirelesss router & $\begin{array}{l}\text { Menghubungkan } \\
\text { beberapa jaringan }\end{array}$ \\
\hline 11 & Modem internet & $\begin{array}{l}\text { Menghubungkan } \\
\text { jaringan lokal } \\
\text { internet ke }\end{array}$ \\
\hline 12 & Laptop /PC & Mengolah data \\
\hline
\end{tabular}

Setelah identifikasi hardware dilakukan kemudian kemudian melakukan identifikasi kebutuhan perangkat lunak seperti kebutuhan interface. Identifikasi kebutuhan user interface dilakukan untuk mengetahui kebutuhan yang dihadapi oleh pengguna aplikasi sistem monitoring dalam penelitian ini :

Identifikasi kebutuhan user interface dilakukan untuk mengetahui kebutuhan yang dihadapi oleh pengguna aplikasi sistem monitoring dalam penelitian ini :

1. Identifikasi Kebutuhan user

Identifikasi kebutuhan user dilakukan untuk mengetahui kebutuhan apa saja yang dibutuhkan oleh pengguna (user) untuk aplikasi sistem monitoring yang akan dirancang.

2. Pihak Facility Engineering

Merupakan jenis pengguna yang memiliki tugas memonitoring suhu dan kelembaban udara dan melakukan Action perbaikan ketika suhu dan kelembaban udara pada ruang produksi terdeteksi tidak normal.

3. Pihak Quality Control

Merupakan jenis pengguna yang memiliki 
tugas me-monitoring suhu dan kelembaban udara dan mendokumentasikan data pembacaan suhu dan kelembaban udara pada ruang produksi secara berkala dan merekomendasikan penyelamatan produk ketika suhu dan kelembaban udara terdeteksi tidak normal.

Perancangan dimulai dengan merancang diagram blok perangkat keras untuk mengetahui prinsip kerja alat, kemudian dilanjutkan merancang rangkaian alat dengan menggabungkan keseluruhan perangkat menjadi sebuah sistem terkendali. Gambar 4 merupakan diagram blok dari perangkat keras sistem monitoring suhu dan kelembaban udara menggunakan teknologi wireless sensor network yang memanfaatkan modul wifi nodemcu sebagai pengirim data ke server dan disimpan didalam database.

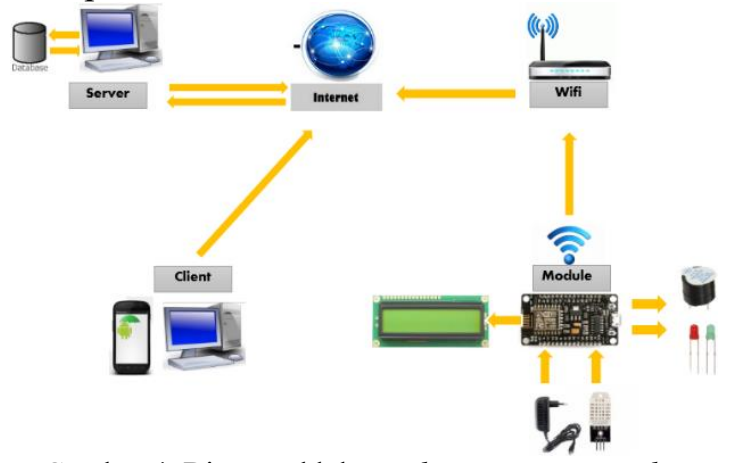

Gambar 4. Diagram blok wireless sensor network

Gambar 4. Diagram wireless sensor network (wsn) menunjukkan diagram blok dan prinsip kerja alat atau sistem wsn secara umum. Terdapat beberapa perangkat keras yang digunakan seperti microcontroller nodemcu,sensor DHT22, power supply, buzzer, LED, LCD, wifi router, modem, dan komputer. Alat-alat ini akan bekerja dengan saling terintegrasi dimana prinsip kerja rangkaian alat atau sistem adalah sebagai berikut:

1. Server berfungsi sebagai pengelola sistem dengan tugas mengelola data, memproses data yang diterima dari perangkat keras, mengirimkan data kembali ke ketika diakses oleh user.

2. Nodemcu berfungsi sebagai pengontrol sistem dengan tugas menerima input data dari sensor, mengirim data ke server.
3. Sensor dht22 berfungsi sebagai pendeteksi suhu dan kelembaban udara

4. LED berfungsi sebagai indikator kondisi normal atau tidak normal.

5. Buzzer berfungsi sebagai alarm peringatan kondisi tidak normal .

6. LCD sebagai display monitor pada perangkat keras

7. Catudaya sebagai suplay arus dan tegangan listrik kepada semua komponen

8. Wifi router sebagai pengirim paket data ke jaringan internet

Microcontroller yang digunakan adalah nodemcu dengan menggunakan driver IC CH340 yang tergabung dengan modul wifi esp8266 dalam satu board yang digunakan sebagai pengolah data dan pengirim data, karena dimensi modul yang kecil dan memiliki jumlah pin yang dapat memenuhi kebutuhan sistem yang akan dibuat Sehingga sangat praktis dan mudah digunakan.perancangan rangkaian skemtik perangkat keras dilakukan untuk menentukan pengkabelan nodemcu dengan modul-modul pendukung dan antar perangkat keras dalam system. Pada penelitian ini rangkaian elektronika yang diterapkan cukup sederhana, untuk komunikasi perangkat keras dapat langsung dihubungkan pada pin dimasingmasing port yang ada pada nodemcu. Tabel 4 merupakan komponen dengan koneksi port pada nodemcu.

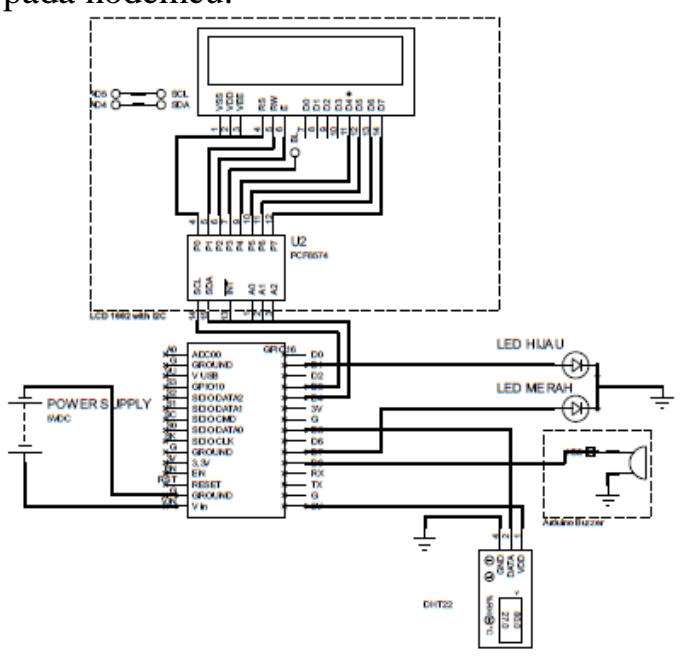

Gambar. 5. Rancangan skematik hardware 


\begin{tabular}{|c|c|c|}
\hline \multicolumn{3}{|c|}{$\begin{array}{c}\text { TABEL } 4 . \\
\text { KOMPONEN KONEKSI PORT PADA NODEMCU }\end{array}$} \\
\hline $\begin{array}{l}\text { Komponen } \\
\text { hardware }\end{array}$ & $\begin{array}{l}\text { Koneksi } \\
\text { GPIO }\end{array}$ & Fungsi \\
\hline LED merah & D2/GPIO4 & kondisi normal \\
\hline LED hijau & D1/GPIO5 & Kondisi abnormal \\
\hline Sensor DHT22 & D5/GPIO14 & $\begin{array}{l}\text { Deteksi suhu dan } \\
\text { kelembaban }\end{array}$ \\
\hline buzzeer & D8/GPIO15 & Alarm peringatan \\
\hline Lcd 1602 I2C & $\begin{array}{l}\mathrm{SDA}=\mathrm{D} 4 / \mathrm{G} \\
\mathrm{PIO} 0 \\
\mathrm{SCL}=\mathrm{D} 3 / \mathrm{GP} \\
\mathrm{IO} 2\end{array}$ & $\begin{array}{l}\text { Menampilkan } \\
\text { informasi }\end{array}$ \\
\hline
\end{tabular}

Tahap instalasi hardware/perangkat keras merupakan tahap pembuatan perangkat keras yang sudah dirancang pada tahap sebelumnya. Pada tahap ini meliputi pembuatan pembuatan box sebagai tempat rangkaian komponen, rangkaian elektronika, pembuatan source code Arduino dan penggabungan antara source code dan rangkaian elektronika. Gambar 6 adalah hasil dari intalasi perangkat keras dalam penelitian ini sesuai dengan perancangan hardware yang telah direncanakan sebelumya.

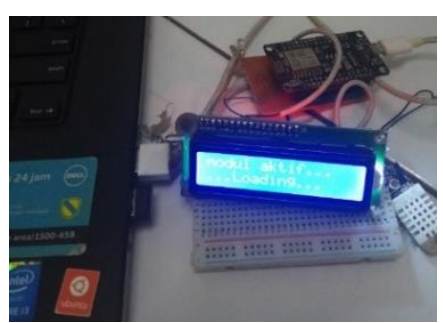

Gambar. 6. Instalasi hardware

Setelah perangkaian hardware dilakukan kemudian menyiapkan router dan modem sebagai media pengiriman data ke server dengan SSID dan password yang ada padaa perusahaan.

Pada tahap ini dilakukan hasil perancangan interface menggunakan bahasa pemrograman HTML dan PHP, kemudian database menggunakan MySQL.

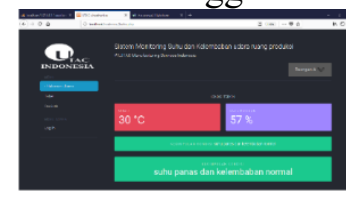

(A) Halaman Menu Utama

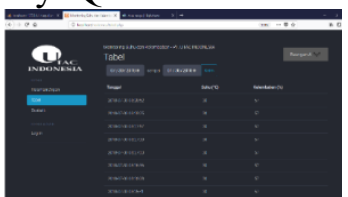

(B) Halaman Menu Tabel

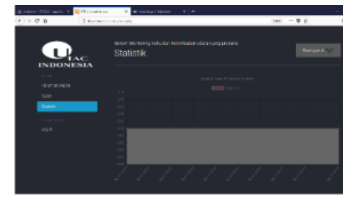

(C) Halaman Menu Grafik

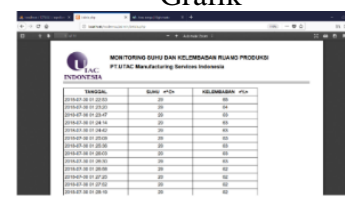

(E) Halaman Cetak Data

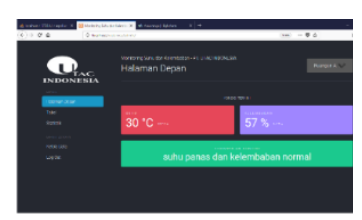

(D) Halaman Utama Admin

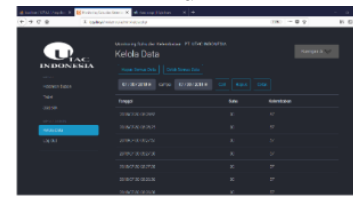

(F) Halama Admin Hapus Data
Gambar. 7. Interface sistem monitoring

Gambar 7 (A) merupakan hasil pengkodean untuk tampilan halaman menu utama dimana user dapa melihat nilai suhu dan kelembaban ter-update yang dikirim oleh sensor di ruang produksi. Gambar 6 (B) merupakan hasil pengkodean untuk tampilan halaman tabel suhu dan kelembaban. Pada menu ini terdapat menu search data yang bisa dilihat per tanggal. Gambar 7 (C) merupakan hasil pengkodean untuk tampilan menu grafik suhu dan kelembaban. Gambar 7 (D) merupakan hasil pengkodean untuk tampilan halaman utama admin yang terdapat dua tombol menu tambahan yaitu cetak data dan hapus data. Gambar 7 (E) merupakan hasil pengkodean untuk tampilan halaman admin cetak data yang berfungsi untuk kebutuhan cetak data seuai kebutuhan dan file dikonversi menjadi format .PDF terlebih dahulu. Gambar 7 (F) merupakan hasil pengkodean untuk tampilan halamanadmin hapus data yang berarti admin memiliki akses untuk menghapus data yang sudah tidak diperlukan.

Pengujian akan dilakukan untuk menguji apakah node sensor dapat bekerja dengan baik atau tidak dalam mengirimkan data dan menguji tingkat keakuratan nilai pembacaan sensor dht22 ketika dibandingkan dengan alat yang sudah ada pada ruang produksi berupa hygrothermograph. Dari hasil pengujian sensor dht 22 dengan 15 kali pengiriman dibandingkan dengan pengukuran yang dilakukan hygrothermograph dapat diperoleh data pada tabel 5 sebagai berikut. 
TABEL 5

PERBANDINGAN HASIL PENGUKURAN SUHU SENSOR DH DHT22

\begin{tabular}{|c|c|c|c|}
\hline \multirow[b]{2}{*}{$\begin{array}{c}\text { Pengujian } \\
\text { ke }\end{array}$} & \multicolumn{2}{|c|}{ Nilai suhu $\left({ }^{\circ} \mathbf{C}\right)$} & \multirow[b]{2}{*}{$\begin{array}{c}\text { Akurasi } \\
(\%)\end{array}$} \\
\hline & $\begin{array}{l}\text { Sensor } \\
\text { dht } 22\end{array}$ & $\begin{array}{c}\text { Hygrothermo } \\
\text { graph }\end{array}$ & \\
\hline 1 & 21 & 22 & 95,5 \\
\hline 2 & 23 & 24 & 95,8 \\
\hline 3 & 22 & 22 & 100,0 \\
\hline 4 & 21 & 22 & 95,5 \\
\hline 5 & 22 & 24 & 91,7 \\
\hline 6 & 22 & 22 & 100,0 \\
\hline 7 & 21 & 21 & 100,0 \\
\hline 8 & 22 & 23 & 95,6 \\
\hline 9 & 23 & 24 & 95,8 \\
\hline 10 & 21 & 23 & 91,4 \\
\hline 11 & 23 & 23 & 100,0 \\
\hline 12 & 22 & 23 & 95,7 \\
\hline 13 & 22 & 22 & 100,0 \\
\hline 14 & 21 & 23 & 91,3 \\
\hline 15 & 21 & 22 & 95,5 \\
\hline \multicolumn{3}{|c|}{ Averege } & 96,2 \\
\hline
\end{tabular}

TABEL 6.

PERBANDINGAN HASIL PENGUKURAN KELEMBABAN

\begin{tabular}{|c|c|c|c|}
\hline \multirow{2}{*}{$\begin{array}{l}\text { Pengujian } \\
\text { ke }\end{array}$} & \multicolumn{2}{|c|}{ Nilai kelembaban (\%) } & \multirow{2}{*}{$\begin{array}{c}\text { Akurasi } \\
(\%)\end{array}$} \\
\hline & $\begin{array}{l}\text { Sensor } \\
\text { dht } 22\end{array}$ & $\begin{array}{l}\text { Hygrothermo } \\
\text { graph }\end{array}$ & \\
\hline 1 & 44 & 48 & 91,7 \\
\hline 2 & 44 & 47 & 93,7 \\
\hline 3 & 45 & 48 & 93,8 \\
\hline 4 & 41 & 46 & 89,1 \\
\hline 5 & 44 & 49 & 89,8 \\
\hline 6 & 42 & 46 & 91,3 \\
\hline 7 & 47 & 51 & 92,2 \\
\hline 8 & 46 & 50 & 92,0 \\
\hline 9 & 43 & 48 & 89,6 \\
\hline 10 & 42 & 46 & 91,3 \\
\hline 11 & 43 & 48 & 89,6 \\
\hline 12 & 45 & 50 & 90,0 \\
\hline 13 & 42 & 47 & 89,4 \\
\hline 14 & 46 & 49 & 93,9 \\
\hline 15 & 44 & 47 & 93,6 \\
\hline \multicolumn{3}{|c|}{ Averege } & 90,0 \\
\hline
\end{tabular}

Tabel 6 dan 7 menunjukkan bahwa dari hasil pengujian yang dilakukan dengan $15 \mathrm{kali}$ uji pembacaan suhu dan kelembaban pada ruang produksi inlet dan smart card menggunakan sensor dht22 dibandingan dengan pembacaan hygrothermograph menunjukan tingkat akurasi dari sensor dht 22 adalah $96,2 \%$ pada pembacaan suhu dan 90,0\% pada pembacaan kelembaban udara.

\section{Kesimpulan}

Berdasarkan tahapan - tahapan penelitian yang telah dilakukan terhadap permasalahan kondisi ruang produksi komponen semikonduktor pada PT. XXX, usulan sistem yang telah diaplikasikan dan hasil pengujian serta analisis alat sistem monitoring suhu dan kelembaban udara maka disimpulkan beberapa hal sebagai berikut. Pertama Peringatan terhadap perubahan suhu dan kelembaban pada ruang produksi efektif untuk membantu karyawan dalam melakukan penyelamatan matrial produksi yang sangat rentan terhadap perubahan suhu sehingga matrial tidak terjadi perubahan kualitas baik secara visual maupun secara fungsi. Kedua Dengan pengaplikasian sistem monitoring suhu dan kelembaban udara ini sangat tepat, ini dapat dilihat dari serangkaian pengujian dengan bebrapa kondisi. Alat ini berfungsi normal, sesuai fungsional alat yang dibangun untuk memonitoring suhu dan kelembaban udara hal ini berdasarakan pengujian yang telah dilakukan memiliki tingkat akurasi dht 22 adalah 96,2\% pada pembacaan suhu dan 90,0\% pada pembacaan kelembaban udara.

Penelitian ini masih memiliki banyak kekurangan untuk itu ada beberapa saran untuk diteliti lebih lanjut pertama data yang dikirimkan dari node secara terus menerus akan mengirimkan data keserver hal ini akan membuat boros energi yang ada pada node sehingga belum efesien terhadap pengguna energy listrik di sisi node. Proses pengumpulan dan pengiriman data akan lebih efesien lagi kalau menerapkan kecerdasan disisi node sensor sehingga kapan waktu pengirim data ke server dan data mana yang dikirimkan sudah ditentukan disisi node.

\section{Daftar Pustaka}

Abdullah, M. (2016). Fisika Dasar 1. Bandung

Al-Karaki JN, Kamal AE. (2004). Routing techniques in wireless sensor networks: A survey. IEEE Wireless Communications, 11(6), 6-28.

Bokare M, Ralegaonkar A. Wireless Sensor Network. IJCES. 2 (2012) : Issue 3.

Bayu. (2018, juli 20). Apa itu kelembaban. Diambil kembali

dari 
http://www.bestairdehumd.com.

Budioko, T. , (2016). Sistem Monitoring Suhu Jarak Jauh Berbasis Internet Of Things Menggunakan Protokol Mqtt, 1(1),353-358

Muladi, Herwanto, H.W., \& Hidayat, S. (2016). Implementasi Wireless Sensor Network Untuk Monitoring ruang Kelas Sebagai Bagian Dari Internet Of Things 52(22), 1693-8739

Mukherjee S. (2013). Star Topology as Central Topology in aHybrid Model. IJERT. 2 (2) : $2278-0181$.

Rozikin, Sukoco, Saptomo. (2017). Sistem Akuisisi Data Multi Node untuk Irigasi Otomatis Berbasis Wireless Sensor Network. JNTETI. Vol 6. No 1.

Wang N, Zhang N, Wang M. (2006). Wireless Sensors in Agriculture and Food Industry Recent Development and Future Perspective. Computers and Electronics in Agriculture 50 (2006) : 1-14 